\title{
Dasycladalean algae from Upper Jurassic-Lower Cretaceous limestones of Piatra Craiului Massif (South Carpathians, Romania) and their relationship to paleoenvironment
}

\author{
Cristian Victor MIRCESCU ${ }^{1 *}$, Ioan I. BUCUR ${ }^{1}, \&$ Emanoil SĂSĂRAN ${ }^{1}$ \\ ${ }^{1}$ Babeş-Bolyai University, Department of Geology, Kogălniceanu 1, 400084 Cluj-Napoca, Romania
}

Received: April 2014; accepted May 2014

Available online 16 June 2014

DOI: http://dx.doi.org/10.5038/1937-8602.59.1.1

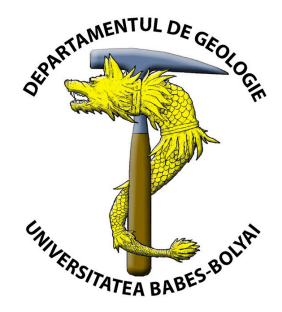

\begin{abstract}
The Mesozoic limestones of Piatra Craiului Massif were deposited in the Dâmbovicioara sedimentary area, at the easternmost part of the Getic carbonate platform. In order to study the microfacies and to provide a more detailed biostratigraphy, we sampled the carbonate succession from Piatra Craiului Massif along several sections. Identified microfacies point to reef slope, carbonate platform margin and restricted, lagoon-type internal depositional environments. Some of the identified microfossils are biostratigraphic markers for the Tithonian-Lower Valanginian. The calcareous algae form associations typical for reef slopes and internal platforms. The latter can be subdivided into: (1) restricted environments (low-energy subtidal-intertidal) dominated by rivulariacean-type cyanobacteria, and (2) open-marine environments (moderate to high-energy subtidal) where dasycladalean algae are more frequent.
\end{abstract}

Keywords: dasycladalean algae, paleoenvironment, platform carbonates, Upper Jurassic-Lower Cretaceous

\section{INTRODUCTION}

During the Late Jurassic-Early Cretaceous, the dasycladalean algae flourished, with some species recording acmes during relatively short stratigraphic intervals (Bassoullet et al., 1978; Barattolo, 1991; Berger and Kaever, 1992; Granier and Deloffre, 1993; Bucur, 1999). As a rule, fossil algae ecology can be deduced by extrapolating environmental observations made on present-day calcareous algae. The latter populate various marine environments, from high-energy reefs to low-energy lagoons. They prefer tropical warm waters, around $20^{\circ} \mathrm{C}$ annual average values (Roux, 1995; De Castro, 1997; Valet, 1979).

Our study focuses on the relationship of some dasycladalean algae with their depositional environment. Based on sedimentary features and associated microfossils, we evidenced several depositional environments. Each of them favored the development of a variable number of species controlled by several ecological key-factors.

We have sampled four sections in the Piatra Craiului carbonate succession: Padina Închisă-Lehmann's trail, West Vlăduşca-East Vlăduşca, Zaplaz-Lanţuri, and Padina Lăncii (Fig. 1). All the samples from these sections were investigated in order to describe the main type of microfacies and microfossils.

\section{GEOLOGICAL FRAMEWORK}

The $25 \mathrm{~km}$-long, NE-SW oriented calcareous mountain crest forming the Piatra Craiului Massif is located in eastern part of the Southern Carpathians (Fig. 1), forming the western flank of a large synclinal unit (Popescu, 1966; Patrulius, 1969). On the top of the crystalline basement assigned to the Cumpăna and Leaota formations, a sedimentary succession consisting of KimmeridgianLower Valanginian calcareous deposits is found in the Piatra Craiului Syncline (Bucur et al., 2009). Bajocian-Oxfordian terrigenous and carbonate rocks consisting of microconglomerates, sandstones and marly-limestones passing towards the top into radiolarites with marl and calciturbidite interlayers, and jaspers form the base of this succession (Popescu, 1966; Bucur, 1978; Bucur, 1980; Mészaros and Bucur, 1980; Beccaro and Lazăr, 2007). Next in the succession are white, massive or stratified limestones; when present, the layers are in the order of meter- to centimeter-decimeter- thick. The massive limestones consist of coral bioconstructions and fore-reef rudstones (Fig. 2a-b). They crop-out in lower part of the carbonate succession and correspond to the platform margin. Meters to centimeter-thick layered (peritidal) limestones developed in the upper part of the succession are rich in bioclasts (Fig. 2c-e; g-h) and show frequent fenestral structures (Fig. 2f). Within these peritidalites, we could identify all of the three depositional subenvironments (subtidal, intertidal and supratidal) described below. They migrate laterally and may present typical variations within the calcareous massif.

On the whole, the succession is interpreted as a shallowing upward prograding megasequence of Kimmeridgian-Lower Valanginian age (Bucur et al., 2009; Mircescu et al., 2013; Pleş et al., 2013) (Fig. 3).

\section{Microfacies and microfossils}

A number of 720 thin sections have been made and microscopically investigated; they allowed the separation of eight major microfacies types (MF type 1-MF type 8) (Table 1): coarse bioclastic rudstone, coral-microbial boundstone, 


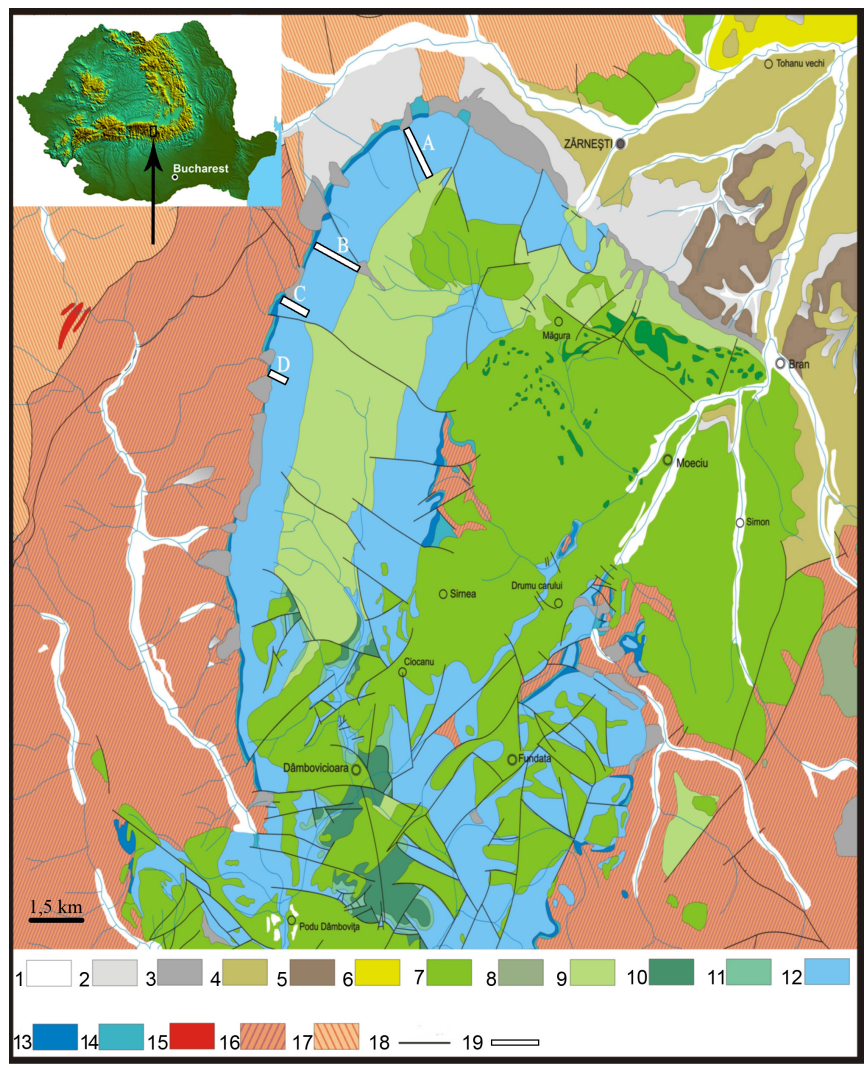

Fig. 1. Location of sampled sections from Piatra Craiului Massif on the geological map of Piatra Craiului-Dâmboviciara area (modified after the geological map of Romania, scale 1: 50000, sheets 110a-d, Dimitrescu et al., 1971; Patrulius et al., 1971; Săndulescu et al., 1972 and Dimitrescu et al., 1974). A) Padina Închisă-Lehmann's Trail section; B) Western Vlăduşca-Eastern Vlăduşca section; C) Zaplaz-Lanţuri section; D) Padina Lăncii section; 1-3) Quaternary deposits 4,5) Cenozoic deposits 6) Turonian-Maastrichtian 7) Uppermost Albian-Cenomanian 8) Albian 9) Aptian 10) Barremian 11) Hauterivian 12) KimmeridgianLower Valanginian 13) Callovian-Oxfordian 14) Bajocian-Callovian 15) Magmatic rocks 16) Leaota metamorphic formation 17) Cumpăna metamorphic formation 18) Fault 19) Sampled sections.

Table 1. The main microfacies identified in the studied zone and their relationship with the paleoenvironment.

\begin{tabular}{|c|c|c|c|}
\hline $\begin{array}{c}\text { MF } \\
\text { number }\end{array}$ & Microfacies description & Paleoenvironment & Illustration \\
\hline 1 & Coarse bioclastic rudstone & $\begin{array}{c}\text { Reef slope and platform } \\
\text { margin }\end{array}$ & Plate II, Figs. 1-4 \\
\hline 2 & $\begin{array}{c}\text { Coral-microbial } \\
\text { boundstone }\end{array}$ & $\begin{array}{c}\text { Reef slope and platform } \\
\text { margin }\end{array}$ & Plate II, Figs. 5-8 \\
\hline 3 & $\begin{array}{c}\text { Bioclastic intraclastic grainstone } \\
\text { with black pebbles }\end{array}$ & $\begin{array}{c}\text { High energy internal } \\
\text { platform subtidal }\end{array}$ & Plate III, Figs. 1-6 \\
\hline 4 & $\begin{array}{c}\text { Grainstone with } \\
\text { regenerated ooids }\end{array}$ & $\begin{array}{c}\text { High energy internal } \\
\text { platform subtidal }\end{array}$ & Plate III, Figs. 7-8 \\
\hline 5 & $\begin{array}{c}\text { Fenestal bioclastic wackestone } \\
\text { pow energy internal } \\
\text { platform subtidal }\end{array}$ & Plate IV, Figs. 1-6 \\
\hline 7 & $\begin{array}{c}\text { Bindstone with } \\
\text { cyanobacteria }\end{array}$ & Intertidal-supratidal & Plate V, Fig. 1 \\
\hline 8 & $\begin{array}{c}\text { Fenestral bioclastic packstone- } \\
\text { grainstone }\end{array}$ & $\begin{array}{c}\text { Intertidal-supratidal } \\
\text { non-fossilifenonous mudstone }\end{array}$ & Plate V, Figs. 7-8 \\
\hline
\end{tabular}

bioclastic-intraclastic grainstone with black pebbles, grainstone with regenerated ooids, fenestral bioclastic wackestone, bindstone with cyanobacteria, fenestral-bioclastic packstone/grainstone, and homogenous non-fossiliferous mudstone. MF type 1 and MF type 2 are the main component of reef slope and platform margin environments while MF type 3-MF types 8 are characteristic for peritidal environments (internal platform with high and low

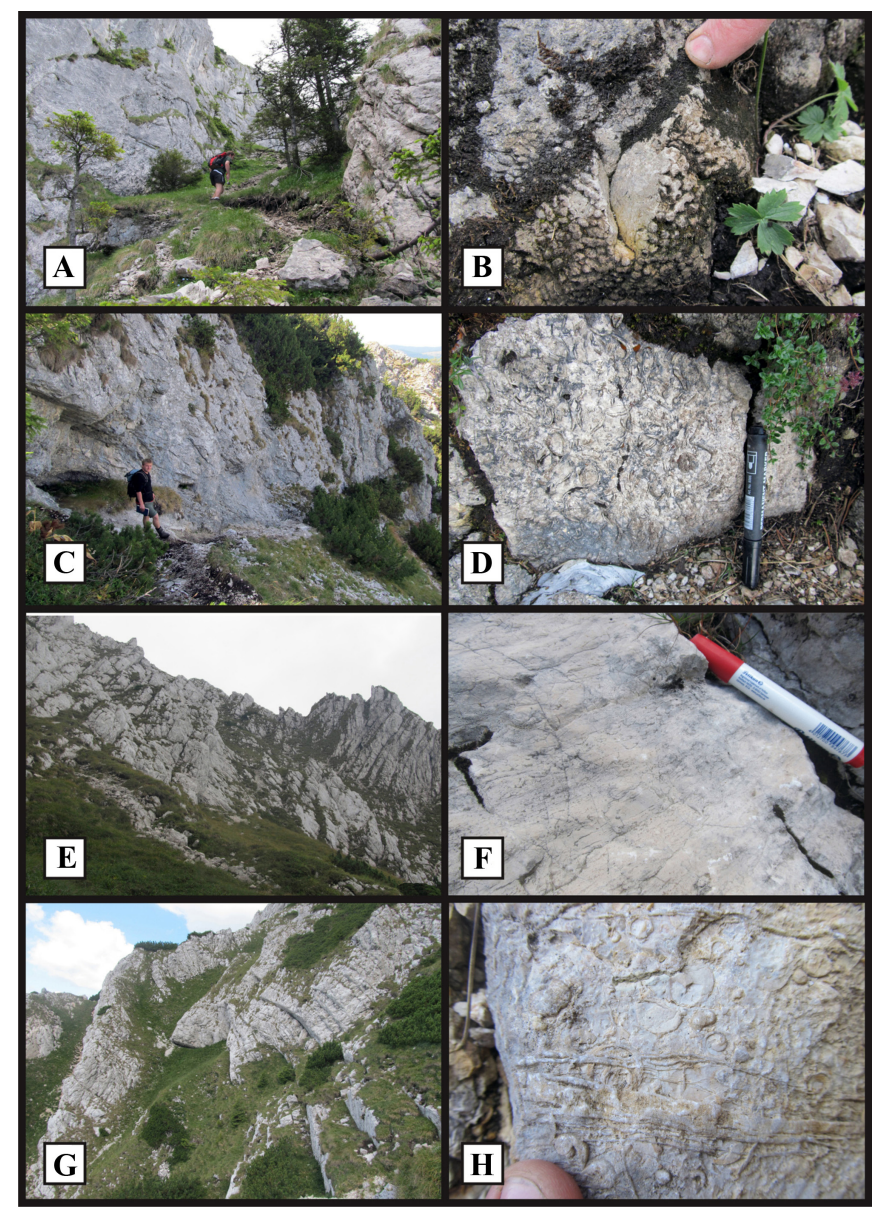

Fig. 2. Outcrop aspects of the Upper Jurassic-Lower Cretaceous limestones from Piatra Craiului. A) Massif limestones in the lower part of Vlăduşca section; B) Coral bioconstructions; C) Peritidal limestones in the middle-upper part of the Padina Inchisă section; D) Rudist-bearing bioclastic wackestone, Padina Inchisă section; E) Meter bedded limestones in the middle-upper part of the Vlăduşca section (Scale: $1 \mathrm{~m}$ ); F) Laminoid-fenestral limestones, Vlăduşca section; G) Decimeter to meter bedded limestones in the upper part of the Zaplaz-Lanturi section; H) Bioclastic limestones with gastropods, Zaplaz-Lanţuri section.

energy, intertidal, supratidal). The most important microfossils (foraminifera and dasycladalean algae) are shown in Pl. I-VIII.

\section{Microfacies type 1 (coarse bioclastic rudstone)}

In the lower part of the studied sections, Kimmmeridgian limestones are built-up of the typical rudstones of reef slope environments (Pleş et al., 2013). They are frequently associated with coral-microbial boundstones (MF type 2). Within the rudstones, poorly sorted angular-subangular clasts indicate limited transportation (Pl. II, Figs. 1, 2). Bioclasts consist of bivalve shells, gastropod fragments, corals, echinoderm plates, bryozoans, worm tubes, juvenile ammonites and foraminifers (Pl. II, Figs. 3, 4).

Dasycladalean algae (Salpingoporella pygmaea and Clypeina sulcata) are also present, but with a relatively reduced species diversity. They seem to be dispersed into the bioconstructions internal sediment, or they occur as small fragments mixed with the reef detritus along the fore-reef slope.

\section{Microfacies type 2 (coral-microbial boundstone)}

The boundstones display peloidal bioclastic packstonewackestone-type internal sediment (PI. II, Figs. 5-7). Microbial crusts and encrusting organisms are important constituents, contributing significantly to the reinforcement of the reef 


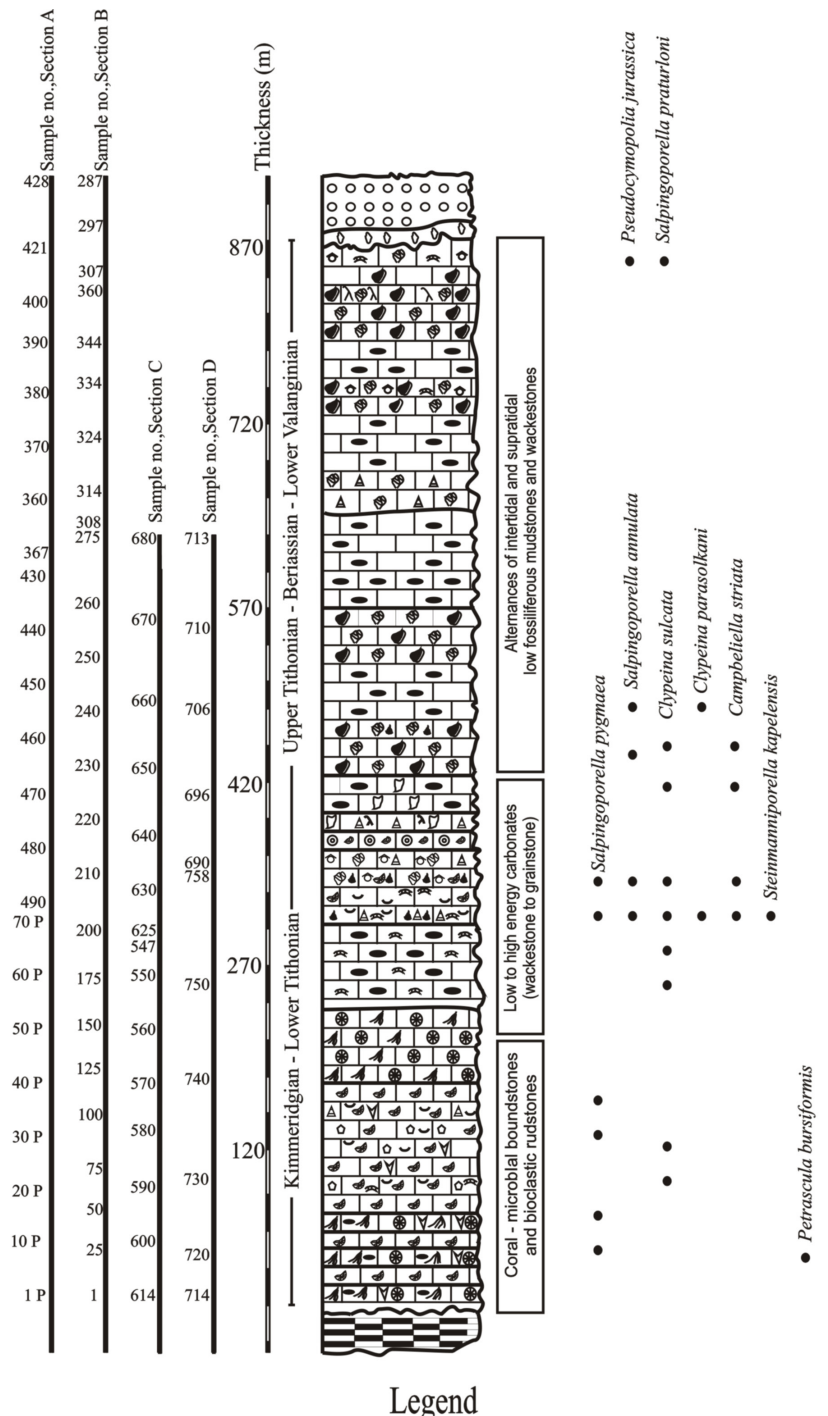

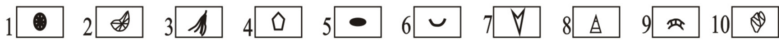

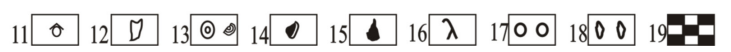

Fig. 3. Generalized stratigraphic succession of the KimmeridgianLower Valanginian limestones from Piatra Craiului. 1) Corals; 2) Coral fragments; 3) Microbial crusts; 4) Echinids; 5) Peloids; 6) Bivalves; 7) Bryozoans; 8) Gastropods; 9) Dasycladalean algae; 10) Rivulariacean-type cyanobacteria; 11) Foraminifers; 12) Rudists; 13) Regenerated ooids; 14) Fenestral structures; 15) Black pebbles; 16) Roots; 17) Latest Albian-Cenomanian conglomerates; 18) Aptian breccia; 19) Oxfordian radiolarites.

framework (Pleş et al., 2013). In some cases, they build-up networks between the coral colonies, or they form associations of encrusting organisms within the sediment between corals (Pl. II, Fig. 8). The bioconstructions occur as intercalations, being installed and developing on top of the rudstone type deposits. Bioconstructions did not merge into large-scale vertical frameworks that could explain the reefal paleoslope. Pleş et al. (2013) considered that the shelf paleoslope derived from the inherited geometry of the carbonate platform basement.

The micropaleontological assemblage identified consists of encrusting organisms [Crescentiella morronensis (Crescenti), bacinellid structures, Lithocodium aggregatum Elliott, Koskinobullina socialis Cherchi \& Schroeder, Iberopora bodeuri Granier \& Berthou, Radiomura cautica Senowbari-Daryan \& Schäfer, interpreted by Senowbari-Daryan (2009) as a sponge], sponges (Murania reitneri Schlagintweit, Neuropora lusitanica Termier, Perturbatacrusta leini Schlagintweit \& Gawlick,
Thalamopora lusitanica Termier \& Termier, Calcistella jachenhausenensis Reitner), foraminifers [Coscinoconus alpinus Leupold, Labyrinthina mirabilis Weynschenk, Mohlerina basiliensis (Mohler), Parurgonina caelinensis Cuvillier, Foury \& Pignatti Morano] and dasycladalean algae [(Clypeina sulcata (Alth), Salpingoporella pygmaea (Gümbel), Petrascula bursiformis (Etallon)].

The bioconstructions are followed by peritidal TithonianBerriasian-Lower Valanginian limestones. They display a wide range of microfacies (MF type 3-MF type 8): bioclasticintraclastic grainstone with black pebbles, grainstone with regenerated ooids, fenestral bioclastic wackestone, bindstone with cyanobacteria, fenestral-bioclastic packstone/grainstone, and homogenous non-fossiliferous mudstone.

\section{Microfacies type 3 (bioclastic-intraclastic grainstone with black pebbles)}

Dasycladalean algae, rivulariacean-type cyanobacteria (Rivularia piae), gastropods, coral fragments, sponges, and Bacinella-type structures are the biota identified in the bioclasticintraclastic grainstones (Pl. III, Figs. 1-6). A millimeter-thick micritic rim is present around the dasycladalean fragments (Pl. III, Figs. 2, 3). We assume that the micritization took place in a low-energy, quiet environment, under the influence of microendoliths (Bathurst, 1966; Flügel, 2004). Subsequently, the dasycladalean algae were reworked and re-deposited in higher-energy environments.

The black pebbles (Pl. III, Figs. 1, 6) indicate stages of subaerial exposure of the carbonate platform as well as relative fluctuations of the sea level. According to Strasser (1984), three models apply to the formation of black pebbles: the first assumes that a black film could form around carbonate clasts in anoxic microenvironments within peritidal areas. A second model considers that organic matter in the sediments blackens the carbonate clasts during the uplift stages of the carbonate platform (Strasser, 1984; Leinfelder, 1987). A third scenario also involves organic matter, but this is adsorbed at the surface of calcretes during pedogenetic micritization processes (Strasser, 1984; Săsăran, 2006). The black pebbles may be reworked, or may be found in situ. In the studied deposits, the pebbles were reworked in the subtidal sediments.

In the Zaplaz-Lanţuri and Padina Lăncii sections, we have identified limestone levels pigmented with iron oxides. They are probably subaerially exposed subtidal carbonate deposits. Dasycladalean algae (frequent Clypeina sulcata and seldom Campbeliella striata) and rare foraminifers are the typical bioclasts in these deposits. Here we have also remarked a second black pebbles level.

\section{Microfacies type 4 (grainstone with regenerated ooids)}

The grainstones with broken and regenerated ooids are frequent in Padina Închisă section. They build-up a 10 m-thick level located on top of the black pebbles-bearing deposits. No bioclasts are present in these sediments (Pl. III, Figs. 7, 8). These limestones formed in high-energy environments, in marginal or internal areas of the shallow carbonate platform (Flügel, 2004).

\section{Microfacies type 5 (fenestral bioclastic wackestone)}

This type of microfacies contains the following sub-types: wackestone with dasycladalean algae, bioclastic wackestone with diceratid rudists and gastropods, bioclastic mudstone/ wackestone (Pl. IV, Figs. 1-6). The bioclasts, represented by large 
gastropods, rudists and cyanobacteria nodules are embedded in a muddy, micritic sediment (Pl. IV, Figs. 1, 2). The micritic sediment is intensely bioturbated. The abundance of gastropods and cyanobacteria nodules (Pl. IV, Figs. 1-4) indicates a lagoontype, quiet, shallow environment (low energy internal platform subtidal environment).

\section{Microfacies type 6 (bindstone with cyanobacteria)}

In the Padina Închisă section, the cyanobacteria may form small bioconstructions (Pl. V, Fig. 1). These contain laminitic stromatolitic structures consisting of very fine peloids alternating with very fine, laminitic, black micrite. Skeletal cyanobacterial stromatolites are associated with the micritic laminites; sometimes they may also build-up thrombolytic fabrics (Pl. V, Fig. 1).

\section{Microfacies type 7 (fenestral-bioclastic packstone/grainstone)}

The following sub-types are characteristic for MF type 7: fenestral peloidal bioclastic wackestone/packstone, packstone with cuneolinid foraminifers, grainstone/packstone with micritized ooids and intraclasts (Pl. IV, Figs. 7-8; Pl. V, Figs. 2-8). The top of the studied sections consists of intertidal-supratidal limestones. On western flank of the Piatra Craiului Massif, these deposits are more than $300 \mathrm{~m}$-thick, while on the eastern side they are only 250 m-thick. The bioclastic wackestone/packstone dominates (Pl. V, Figs. 2, 3). Abundant rivulariacean-type cyanobacteria are the main bioclasts present (Pl. V, Figs. 4, 5, 8) and they indicate restrictive environments. Rare bivalves, gastropods and cuneolinid foraminifers are also present. We have also noticed grains formed under high energy condition (ooids) that were afterwards reworked into intertidal environments and micritized (Pl. V, Fig. 6). In similar depositional environments, micritization processes are often associated with low carbonate sediment accumulation rates (Enos, 1983; Flügel, 2004).

\section{Microfacies type 8 (homogenous non-fossiliferous mudstone)}

This type of microfacies lacks microfossils almost entirely. Sometimes dolomitization is present, mainly located along fissures. In addition, we noticed diffuse structures resembling calcretes in the East Vlăduşca section; they may include root tracks.

The micropaleontological assemblage includes foraminifers [Pseudotextulariella courtionensis Brönnimann, Coscinoconus cherchiae (Arnaud-Vanneau, Boisseau \& Darsac), Conicopfenderina? balkanica Peybernès, Haplophragmoides joukowskyi Charollais, Brönnimann \& Zaninetti, Pfenderina neocomiensis (Pfender), Protopeneroplis ultragranulata (Gorbatchik), Vercorsella camposauri (Sartoni \& Crescenti)], rivulariacean-type cyanobacteria [Rivularia piae (Frollo), Rivularia moldavica (Frollo)], and dasycladalean algae [Campbelliella striata (Carozzi), Steinmanniporella kapelensis (Sokač \& Nikler), Clypeina sulcata (Alth), Clypeina parasolkani Farinacci \& Radoičić, Salpingoporella praturloni (Dragastan), Pseudocymopolia jurassica Dragastan, Salpingoporella annulata Carozzi, Salpingoporella pygmaea (Gümbel)].

\section{The age of the studied deposits}

The micropaleontological assemblages identified in the white limestones from Piatra Craiului Massif (Pls. I, VI-VIII) point to a Kimmeridgian-Lower Valanginian age. Table 2 includes the identified foraminiferal and dasycladalean species, together with their generalized stratigraphic distribution.

The foraminifers Labyrinthina mirabilis and Parurgonina caelinensis are typical species for the Kimmeridgian-Lower
Tithonian interval (Cuvillier et al., 1968; Bassoullet, 1997). They are associated with the algae Salpingoporella pygmaea, Clypeina sulcata, Steinmanniporella kapelensis, Campbelliella striata and Petrascula bursiformis, another typical Kimmeridgian-Tithonian association (Fenninger and Hötzl, 1967; Granier and Deloffre, 1993; Senowbari-Daryan et al., 1994; Bucur, 1999; Schlagintweit and Ebli, 1999; Schlagintweit, 2004; Schlagintweit and Gawlick, 2005; Carras et al., 2006; Schlagintweit, 2011).

The foraminiferal association identified at the top of the succession is characterized by Berriasian-Lower Valanginian speciessuch as Protopeneroplisultragranulata, Pseudotextulariella courtionensis, Haplophragmoides joukowskyi, Pfenderina neocomiensis, or Conicopfenderina? balkanica (Altiner, 1991; Bucur et al., 1995; Bucur, 1997; Peybernès, 2004; Ivanova and Kolodziej, 2010). The accompanying calcareous algae also indicate a Berriasian-Valanginian age: Clypeina parasolkani, Salpingoporella annulata, Pseudocymopolia jurassica, Salpingoporella praturloni (Farinacci and Radoičić, 1991; Granier and Deloffre, 1993; Masse, 1993; Schindler and Conrad, 1994; Bucur, 1999; Dieni and Radoičić, 1999; Moshammer and Schlagintweit, 1999; Schlagintweit et al., 2009).

\section{Relationship between dasycladalean algae and paleoenvironment}

Based on the identified microfacies types and the microfossils, we could separate three principal depositional environments: reef slope and platform margin, internal platform subtidal, intertidal and supratidal.

\section{Reef slope and platform margin environment}

In the lower part of the sampled sections, reef slope carbonate deposits were identified. They are represented by bioclastic rudstone, and boundstone with packstone-wackestone type internal sediment.

Most probably, the algal species identified in the reef rudstone deposits (Clypeina sulcata, Salpingoporella pygmaea) were reworked, as they are dispersed within the mass of grain flows along the fore-reef slope (Pl. VI, Figs. 1-4). We have identified Petrascula bursiformis only in the Padina Lăncii section. Because it is present in packstone-type internal sediment of a coral bioconstruction, we assume that this species is in situ (Pl. VI, Figs. 5-8). Other authors (Schlagintweit, 2011; Bucur and Săsăran, 2012) have described similar large dasycladaleans from similar depositional environments.

\section{Internal platform subtidal environment}

Internal platform subtidal limestones identified in the studied sections formed in both high- and low energy platform environments. High energy subtidal carbonate rocks consist of bioclastic-intraclastic grainstones with black pebbles, or grainstones with regenerated ooids. In the Padina Închisă, West Vlăduşca, and Zaplaz-Lanţuri sections, these deposits are about $60 \mathrm{~m}$-thick. This marker level located on top of the reef limestones can be followed along the whole western flank of the Piatra Craiului Massif.

In the internal platform high energy subtidal deposits, we have identified the following dasycladalean algae: Campbelliella striata, Clypeina sulcata, Salpingoporella annulata, Salpingoporella pygmaea and Steinmanniporella kapelensis (Pl. VII). A micritic rim often surrounds Clypeina sulcata and Salpingoporella pygmaea. We assume that the micritization took place in a low-energy, quiet environment, under the influence of microendoliths. Subsequently, the dasycladalean algae were reworked and re-deposited in higher-energy environments. 
Table 2. Stratigraphic distribution of foraminifera and dasycladalean algae identified in Piatra Craiului Massif.

\begin{tabular}{|c|c|c|c|c|c|}
\hline $\begin{array}{ll}\text { Taxa } & \text { Range } \\
\end{array}$ & Kimmeridgian & Tithonian & Beriassian & Valanginian & Illustration \\
\hline \multicolumn{6}{|c|}{ Foraminifera } \\
\hline $\begin{array}{l}\text { Parurgonina } \\
\text { caelinensis } \\
\text { Cuvillier, Foury } \\
\text { \& Pignatti } \\
\text { Morano, } 1968\end{array}$ & & & & & Pl. I, Fig. 1 \\
\hline $\begin{array}{l}\text { Labyrinthina } \\
\text { mirabilis } \\
\text { Weynschenk, } \\
1951\end{array}$ & & & & & Pl. I, Fig. 2 \\
\hline $\begin{array}{l}\text { Protopeneroplis } \\
\text { ultragranulata } \\
\text { (Gorbatchik, 1971) }\end{array}$ & & & & & Pl. I, Fig. 3 \\
\hline $\begin{array}{l}\text { Pseudotextu- } \\
\text { lariella } \\
\text { courtionensis } \\
\text { Broennimann, } \\
1966\end{array}$ & & & & & Pl. I, Fig. 4 \\
\hline $\begin{array}{l}\text { Haplophragmoides } \\
\text { joukowskyi } \\
\text { Charollais, } \\
\text { Broennimann \& } \\
\text { Zaninetti, } 1966\end{array}$ & & & & & Pl. I, Fig. 5 \\
\hline $\begin{array}{l}\text { Pfenderina } \\
\text { neocomiensis } \\
\text { (Pfender, 1938) }\end{array}$ & & & & & Pl. I, Fig. 6 \\
\hline $\begin{array}{l}\text { Conicopfenderina } \\
\text { ? balkanica } \\
\text { Peybernes, } 2004\end{array}$ & & & & & Pl. I, Fig. 7 \\
\hline \multicolumn{6}{|c|}{ Dasycladalean algae } \\
\hline $\begin{array}{l}\text { Salpingoporella } \\
\text { pygmea (Gümbel, } \\
\text { 1891) }\end{array}$ & & & & & $\begin{array}{l}\text { Pl.VI, Figs. 3-4 } \\
\text { Pl. VII, Fig. } 1\end{array}$ \\
\hline $\begin{array}{l}\text { Salpingoporella } \\
\text { annulata Carozzi, } \\
1953\end{array}$ & & & & & $\begin{array}{l}\text { Pl. VII, Figs. 2-3 } \\
\text { Pl. VIII, Figs. 3-4 }\end{array}$ \\
\hline $\begin{array}{l}\text { Petrascula } \\
\text { bursiformis } \\
\text { (Etallon, 1859) }\end{array}$ & & & & & Pl. VI, Figs. 5-8 \\
\hline $\begin{array}{l}\text { Campbeliella } \\
\text { striata (Carozzi, } \\
1954 \text { ) }\end{array}$ & & & & & Pl. VII, Figs. 7-8 \\
\hline $\begin{array}{l}\text { Clypeina sulcata } \\
\text { (Alth, 1882) }\end{array}$ & & & & & $\begin{array}{l}\text { Pl. IV, Figs. 5-6 } \\
\text { Pl. VI, Figs. 1-2 } \\
\text { Pl. VII, Fig. 5-6 } \\
\text { Pl. VIII, Figs. } \\
1,2,6\end{array}$ \\
\hline $\begin{array}{l}\text { Steinmanniporella } \\
\text { kapelensis (Sokač } \\
\text { \& Nikler, 1973) }\end{array}$ & & & & & Pl. VII, Fig. 4 \\
\hline $\begin{array}{l}\text { Clypeina } \\
\text { parasolkani } \\
\text { Farinacci \& } \\
\text { Radoičić, } 1991\end{array}$ & & & & & Pl. VIII, Fig. 5 \\
\hline $\begin{array}{l}\text { Pseudocymopolia } \\
\text { jurassica } \\
\text { (Dragastan, 1968) }\end{array}$ & & & & & Pl. VIII, Fig. 7 \\
\hline $\begin{array}{l}\text { Salpingoporella } \\
\text { praturloni } \\
\text { (Dragastan, 1978) }\end{array}$ & & & & & Pl. VIII, Fig. 8 \\
\hline
\end{tabular}

by four main species: Clypeina sulcata, Clypeina parasolkani, Salpingoporella praturloni and Pseudocymopolia jurassica (Pl. VIII, Figs. 1-8). The micritic sediment is intensely bioturbated. In these limestones, we have identified numerous specimens of Clypeina sulcata. They occur in abundance as monospecific, whole-fossils in a wackestone microfacies and can be interpreted as being in situ. This species frequently prefers restrictive environments with high salinity (Conrad, 1977).

Favre and Richard (1927) have described Clypeina sulcata (as Clypeina jurassica) from lagoonal limestones, a typical restrictive environment.

Salpingoporella praturloni and Pseudocymopolia jurassica prefer external platform environments (Bucur and Săsăran, 2005), but they seem also to occur in highenergy open-marine internal platform settings; they have been identified at the top of the Padina Inchisă- Lehmann's trail section, in bioclastic wackestones, probably reworked from areas of higher energy sedimentation.

The intertidal and supratidal environments

The top of the studied sections consists of intertidal-supratidal limestones. On the western flank of the Piatra Craiului Massif, these deposits are more than 300 $\mathrm{m}$-thick, while on the eastern side they are only $250 \mathrm{~m}$-thick. Dasycladalean algae are almost completely absent. Within the micritic sediment, the rivulariaceantype cyanobacteria are either isolated, or incorporated in the fenestral sediment (Pl. VIII, Fig. 5). Occasionally, the cyanobacteria incorporate peloids or ostracods. Rivularia moldavica is the dominant species (Pl. VIII, Fig. 4). According to Săsăran et al. (2013), in the intertidal limestones from Piatra Craiului the rivulariacean-type cyanobacteria are the main producers of carbonate, under the circumstances of a progressive decrease of the accommodation space rate of formation in parallel with the progradation of the carbonate platform.

As a rule, Steinmanniporella kapelensis is present in deposits formed on carbonate platform margins (Bucur and Săsăran, 2012), as it is also the case in the Piatra Craiului area.

Salpingoporella annulata was identified in both normal marine (Jafrezo and Renard, 1979), and restrictive (Bucur and Săsăran, 2005) environments. Similarly, in Piatra Craiului this species is present in both open sea deposits (platform margin), and in restrictive, internal platform deposits.

In the upper part of the studied sections the limestones show typical features for restrictive environments (internal platform subtidal with low energy) with rare intercalations of higher energy deposits. The dasycladalean algae dominate the wackestone and fenestral packstone/grainstone facies types. They are represented
The limestones formed in supratidal environments almost lack microfossils. One microfacies type characterizes this depositional environment: non-fossiliferous mudstone.

\section{CONCLUSIONS}

The Kimmeridgian-Lower Valanginian carbonate succession from the Piatra Craiului Massif consists of deposits formed in a wide range of depositional environments. They indicate a general transition from platform margin to internal platform carbonate deposits. Jointly with the progradation of the carbonate platform, the water became shallower. Therefore, in the internal areas of the carbonate platform, restrictive, lagoon- or intertidal 
pond-type environments developed. The relative sea level changes have directly influenced the flora and fauna development. In the restrictive environments, cyanobacteria have flourished, while some dasycladalean algae such as Clypeina sulcata, Salpingoporella annulata, or Clypeina parasolkani developed optimally in the lagoons. More frequently dasycladaleans have been identified in the carbonate platform margin. In spite of the relatively reduced diversity, dasycladaleans, in association with other fossils and the microfacies are useful tools in the reconstruction of the evolution of the Piatra Craiului carbonate platform during the Upper Jurassic-Lower Cretaceous.

Acknowledgements. This work was possible with the financial support of Babeş-Bolyai University (Scientific Performance Scholarship Programme for 2014) and through PN-II-IDPCE-2011-3-0025 grant. The authors would like to thank Felix Schlagintweit and Marc Conrad for their valuable suggestions regarding revision of this paper. Also, they would like to thank the Administration of Piatra Craiului National Park for providing acces in the studied region. The lead author thanks his father, Victor Mircescu, George Popa and George Pleş for assistance in the field.

\section{REFERENCES}

Altiner, D. 1991, Microfossil biostratigraphy (mainly foraminifers) of the Jurassic-Lower Cretaceous carbonate successions in north-western Anatolia, Turkey. Geologica Romana, XXVII: 167-213.

Barattolo, F. 1991, Mesozoic and Cenozoic marine benthic calcareous algae with particular regard to Mesozoic dasycladaleans. In Calcareous algae and stromatolites (Riding, R., Ed.). Springer Verlag, Heidelberg: 504-540. http://dx.doi.org/10.1007/978-3-642-52335-9 22

Bassoullet, J.P., Bernier, P., Conrad, M.A., Deloffre, R. \& Jaffrezo, M. 1978, Les Algues Dasycladales du Jurassique et du Crétacé. Revision critique. Geobios Mémoire Spécial 2, Lyon, 330 p.

Bassoullet, J.P. 1997, Les Grands Foraminifères. In: Biostratigraphie du Jurassique ouest-européen et Méditeranéen: zonations paralleles et distribution et microfossiles (Cariou, E., Hantzpergue, P., Eds.), Bulletin Centre Recherches Elf Exploration-Production, 17: 293-304, Aquitaine.

Beccaro, P., Lazăr, I. 2007, Oxfordian and Callovian radiolarians from the Bucegi Massif and Piatra Craiului Mountains (Southern Carpathians, Romania). Geologica Carpathica, 58 (4): 305-320.

Berger, S., Kaever, J. 1992, Dasycladales. An llustrated monograph of a fascinating algal order. Thieme, Stuttgart, $247 \mathrm{p}$.

Bucur, I.I. 1978, Microfacies of white limestones from the northern part of Piatra Craiului Massif. Biostratigraphical remarks. Dări de seamă ale Şedinţelor Institutului Geologic al României, 64: 89-105 (in Romanian).

Bucur, I.I. 1980, Rhaxella sorbyana (Blake) in Oxfordian radiolarites from Piatra Craiului Massif. Dări de Seamă ale Institutului Geologic al României, 65: 31-35 (in Romanian).

Bucur, I.I. 1997, Representatives of the genus Protopeneroplis (foraminifera) in the Jurassic and Lower Cretaceous deposits in Romania. Comparisons with other regions of the Tethyan Area. Acta Paleontologica Romaniae, 1: 65-74.

Bucur, I.I. 1999, Stratigraphic significance of some skeletal algae (Dasycladales, Caulerpales) of the Phanerozoic. Palaeopelagos Special Publications, 2: 53-104.
Bucur, I.I., Săsăran, E. 2005, Micropaleontological assemblages from the Upper Jurassic-Lower Cretaceous deposits of Trascău Mountains and their biostratigraphic significance. Acta Paleontologica Romaniae, 5: 27-38.

Bucur, I.I., Săsăran, E. 2012, Large dasycladalean algae from Upper Jurassic limestone deposits of the Apuseni Mountains (Romania)-habitat and depositional environment. Geodiversitas, 34 (1): 219-239. http://dx.doi.org/10.5252/g2012n1a12

Bucur, I.I., Conrad, M.A. \& Radoičić, R. 1995, Foraminifers and calcareous algae from the Valanginian limestones in the Jerma River Canyon, Eastern Serbia. Revue de Paléobiologie, 14 (2): 349-377.

Bucur, I.I., Săsăran, E., Iacob, R., Ichim, C. \& Turi, V. 2009, Upper Jurassic shallow-water carbonate deposits from some Carpathian areas: new micropaleontological results. In Proceedings of The 8th Symposium of IGCP 506, Marine and non-marine Jurassic: global correlation and major global events (Popa, M., Ed.), Bucharest, Romania, 1:13-14. Bathurst, R.G.C. 1966, Boring algae, micrite envelopes and lithification of molluscan biosparites. Geology Journal, 5: 15-32. http://dx.doi.org/10.1002/gj.3350050104

Carras, N., Conrad, M.A.\&Radoičić, R. 2006, Salpingoporella, a common genus of Mesozoic Dasycladales (calcareous green algale). Revue de Paléobiologie, 25 (2): 457-517.

Conrad, M.A. 1977, The Lower Cretaceous calcareous algae in the area surrounding Geneva (Switzerland): biostratigraphy and depositional environment. In Fossil algae (Flügel, E., Ed.). Springer, Heidelberg, p. 295-300. http://dx.doi.org/10.1007/978-3-642-66516-5 32

Cuvillier, J., Foury, G. \& Pignatti-Morano,A. 1968, Foraminiferes nouveaux de Jurassique Superieur du Val Cellina (Frioul Occidental, Italie). Geologica Romana, 7: 141-156.

De Castro, P. 1997, Introduzione allo studio in sezione sottile delle dasicladali fossili. Quad Academica Pontaniana, 22: 1-261.

Dieni, I., Radoičić, R. 1999, Clypeina dragastani sp. nov., Salpingoporella granieri sp. nov. and other dasycladalean algae from the Beriassian of Eastern Sardinia. Acta Paleontologica Romaniae, 2: 105-123

Dimitrescu, R., Patrulius, D. \& Popescu, I. 1971, Geological map of Romania, scale 1: 50.000, Rucăr Sheet. Institutul de Geologie şi Geofizică, Bucureşti.

Dimitrescu, R., Popescu, I. \& Schuster A., C. 1974, Geological map of Romania, scale 1: 50.000, Bârsa Fierului Sheet. Institutul de Geologie şi Geofizică, Bucureşti.

Enos, P. 1983, Shelf. In Carbonate depositional environments (Scholle, A.P., Bebour, D.G., Moore, C.H., Eds.), AAPG, Memoir 33: 267-296, Austin.

Farinacci, A., Radoičić, R. 1991, Late Jurassic-Early Cretaceous dasycladales (green algae) from the Western Pontides, Turkey. Geologica Romana, XXVII: 135-165.

Favre, J., Richard, L. A. 1927, Étude du Jurassique supérieur de la Pierre-Châtel et de la cluse de la Balme (Jura méridional). Mémoires de la Société Paléontologique Suisse, XLVI: 1-39.

Fenninger, A., Hötzl, H. 1967, Die Mikrofauna und flora des Plassen und Tressenstein kalkes der Typuslokalitäten (Nördliche Kalkalpen). Jahrbuch für Geologie und Paläontologie, 128 (1): 1-37

Flügel, E. 2004, Microfacies of carbonate rocks. Analysis interpretation and application. Springer Verlag, BerlinHeidelberg-New York, 976 p. 
Granier, B., Deloffre, R. 1993, Inventaire critique des algues dasycladaleans du Jurassique et du Crétace. II partie-les algues dasycladaleans fu Jurassique et du Crétace. Revue de Paléobiologie, 12: 19-65.

Ivanova, D., Kolodziej, B. 2010, Late Jurassic-Early Cretaceous foraminifera from Štramberk type limestones, Polish Outer Carpathians. Studia UBB Geologia, 55 (2): 3-31. http://dx.doi.org/10.5038/1937-8602.55.2.1

Jaffrezo, M., Renard, M. 1979, Éléments traces de calcaires a dasycladales et charophytes. Bulletin Centre Recherches Elf-Aquitaine Exploration-Production, 3: 639-649.

Leinfelder, R. 1987, Formation and significance of black pebbles from the Ota Limestone (Upper Jurassic, Portugal). Facies, 17: 159-170. http://dx.doi.org/10.1007/BF02536780

Masse, J.P. 1993, Early Cretaceous Dasycladales biostratigraphy from Provence and adjacent regions (South of France, Switzerland, Spain). A reference for Mesogean correlations. In Studies on Fossil Benthic Algae (Barattolo, F. et al., Eds.), Bolletino de la Societa Paleontologica Italiana, Special Volume 1: 311-324, Modena.

Mészáros, N., Bucur, I.I. 1980, Oxfordian nannoplancton from Piatra Craiului Massif. Muzeul Bruckenthal. Ştiinţe Naturale, 24: 73-77 (in Romanian).

Mircescu, C.V., Bucur, I.I. \& Săsăran, E. 2013, Microfacies of Upper Jurassic limestones from the northern part of Piatra Craiului Massif, Southern Carpathians, Romania (Vlăduşca and Padina Închisă sections). In Proceedings of the 4th International Geological Students Conference (Drápalová, R., Knížek, M., Švecová, K., Žaludková, K., Eds.), Brno, Czech Republic, 1: 109.

Moshammer, B., Schlagintweit, F. 1999, The Ernstbrunn Limestone (Lower Austria): New data on Biostratigraphy and Applied Geology. Abhandlungen der Geologischen Bundesanstalt, 56 (2): 553-565.

Patrulius, D. 1969, Geology of Bucegi Massif and Dâmbovicioara Couloir. Editura Academiei Republicii Socialiste România, Bucureşti, 222 p (in Romanian).

Patrulius, D., Dimitrescu, R. \& Popescu, I. 1971, Geological map of Romania, scale 1: 50.000, Moieciu Sheet. Institutul de Geologie şi Geofizică, Bucureşti.

Peybernès, B. 2004, Conicopfenderina ? balkanica n. sp. (grand foraminifère benthique), nouveau marqueur du Valanginien des Balkanides (marge nord-téthysienne, Bulgarie). Comptes rendus Palevol, 3: 17-26. http://dx.doi.org/10.1016/j.crpv.2003.09.027

Pleş, G., Mircescu, C.V., Bucur, I.I. \& Săsăran, E. 2013, Encrusting micro-organisms and microbial structures in Upper Jurassic limestones from the Southern Carpathians (Romania). Facies, 59 (1): 19-48. http://dx.doi.org/10.1007/s10347-012-0325-1

Popescu, I. 1966, Contributions to the knowledge of the stratigraphy and geological structure of the Piatra Craiului Massif. Dări de Seamă ale Şedinţelor Institutului Geologic al României, 52 (2): 157-176 (in Romanian).

Roux, A. 1985, Introduction a l'étude des algues fossiles paléozoiques (de la bactérie a la tectonique des plaques). Bulletin Centre Réchèrches Elf-Aquitaine ExplorationProduction, 8: 465-699.

Săndulescu, M., Popescu, I., Săndulescu, J., Mihăilă, N. \& Schuster,A. 1972, Geological map of Romania, scale 1: 50.000, Zărneşti Sheet. Institutul de Geologie şi Geofizică, Bucureşti.
Săsăran, E. 2006, Upper Jurassic-Lower Cretaceous limestones from Trascău Mountains. Cluj University Press, Cluj Napoca, 249 p (in Romanian).

Săsăran, E., Pleş, G., Mircescu, C.V. \& Bucur, I.I. 2013, Peritidal cyclical sequences of Kimmeridgian-Beriassian-? Valanginian limestones from Piatra Craiului Massif (Romania); the role of microbialites and rivulariaceantype cyanobacteria. In Proceedings of the 7th European Symposium on Fossil Algae (Missoni, S., Gawlick, H.-J., Eds.), Schladming-Dachstein, Austria, 1: 116-117.

Schindler, U., Conrad, M.A. 1994, The Lower Cretaceous Dasycladales from the Northwestern Friuli Platform and their distribution in chronostratigraphic and cyclostratigraphic units. Revue de Paléobiologie, 13 (1): 59-96.

Schlagintweit, F. 2004, Murania reitneri n. sp., a new scelorosponge from the Upper Jurassic of the Northern Calcareous Alps (Plassen Formation, Austria and Germany). Austrian Journal of Earth Sciences, 95/96: 37-45.

Schlagintweit, F. 2011, The dasycladalean algae of the Plassen Carbonate Platform (Kimmeridgian-Lower Beriassian): taxonomic inventory and palaeogeographical implications within the platform-basin-system of the Northern Calcareous Alps (Austria, p.p. Germany). Geologica Croatica, 64 (3): 185-206.

Schlagintweit, F., Ebli, O. 1999, New results on Microfacies, Biostratigraphy and Sedimentology of Late Jurassic-Early Cretaceous platform carbonates of the Northern Calcareous Alps, Part I: Tressenstein Limestone, Plassen Formation. Geologie ohne Grenzen Festschrift 150 Jahre Geologische Bundesanstalt, 56 (2): 379-418.

Schlagintweit, F., Gawlick, H.J. 2005, Vercorsella halleinensis n. sp.-A New Cuneoliniform Foraminifera from the Late Tithonian to Early Beriassian (Barmstein Limestones, Plassen Carbonate Platform) of the Northern Calcareous Alps (Austria). Jahrbuch der Geologischen Bundesanstalt, 145 (2): 159-169.

Schlagintweit, F., Dieni, I. \& Radoičić, R. 2009, Two lookalike dasycladalean algae: Clypeina isabellae Masse, Bucur, Virgone \& Delmasso, 1999 from the Berriasian of Sardinia (Italy) and Clypeina loferensis sp. n. from Upper Jurassic of the Northern Calcareous Alps (Austria). Annales Géologiques de la Péninsule Balcanique, 70: 43-59. http://dx.doi.org/10.2298/GABP0970043S

Senowbari-Daryan, D. 2009, Coralline Schwämme aus dem norisch-rhätischen Dachstein-Riff des Gosaukammes (Nördliche Kalkalpen, Österreich) [Coralline sponges from the Norian-Rhaetian Dachstein Reef of the Gosaukamm (Northern Calcareous Alps, Austria)]. Jahrbuch der Geologischen Bundesanstalt, 149: 111-166.

Senowbari-Daryan, D., Bucur, I.I. \& Abate, B. 1994, Upper Jurassic Calcareous Algae from the Madonie Mountains, Sicily. Beiträge für Paläontologie, 19: 227-260.

Strasser, A. (1984), Black pebble occurence and genesis in Holocene carbonate sediments ( Florida Keys, Bahamas and Tunisia). Journal of Sedimentary Petrology, 54 (4): 1097-1109.

Valet, G. 1979, Approche paléoécologique du monde des Dasycladales a partir d'écologie des formes actuelles. Bulletin Centre Recherches Elf-Aquitaine ExplorationProduction, 3: 859-866. 
Plate I. The most important foraminifera identified in the Upper Jurassic-Lower Cretaceous limestones from Piatra Craiului. Scale: 0.5 mm (Figs. 1-2); $0.25 \mathrm{~mm}$ (Figs. 3-7).

Fig. 1. Parurgonina caelinensis Cuvillier, Foury \& Pignatti Morano, longitudinal section; Zaplaz-Lanţuri section, sample 652;

Fig. 2. Labyrinthina mirabilis Weynschenk, longitudinal-tangential section; Padina Lăncii section, sample 743;

Fig. 3. Pseudotextulariella courtionenis Brönnmimann, oblique section; Padina Închisă section, sample 464;

Fig. 4. Protopeneroplis ultragranulata (Gorbatchik), subaxial and tangential sections; Lehmann's Trail section, sample 621;

Fig. 5. Haplophragmoides joukowskyi Charollais, Brönnimann \& Zaninetti, subequatorial section; Padina Închisă section, sample 464. Scale: 0.25 mm;

Fig. 6. Pfenderina neocomiensis (Pfender), oblique section; East Vlăduşca section, sample 350;

Fig. 7. Conicopfenderina? balkanica Peybernès, longitudinal-oblique section; Lehmann's Trail section, sample 411. 
PLATE I

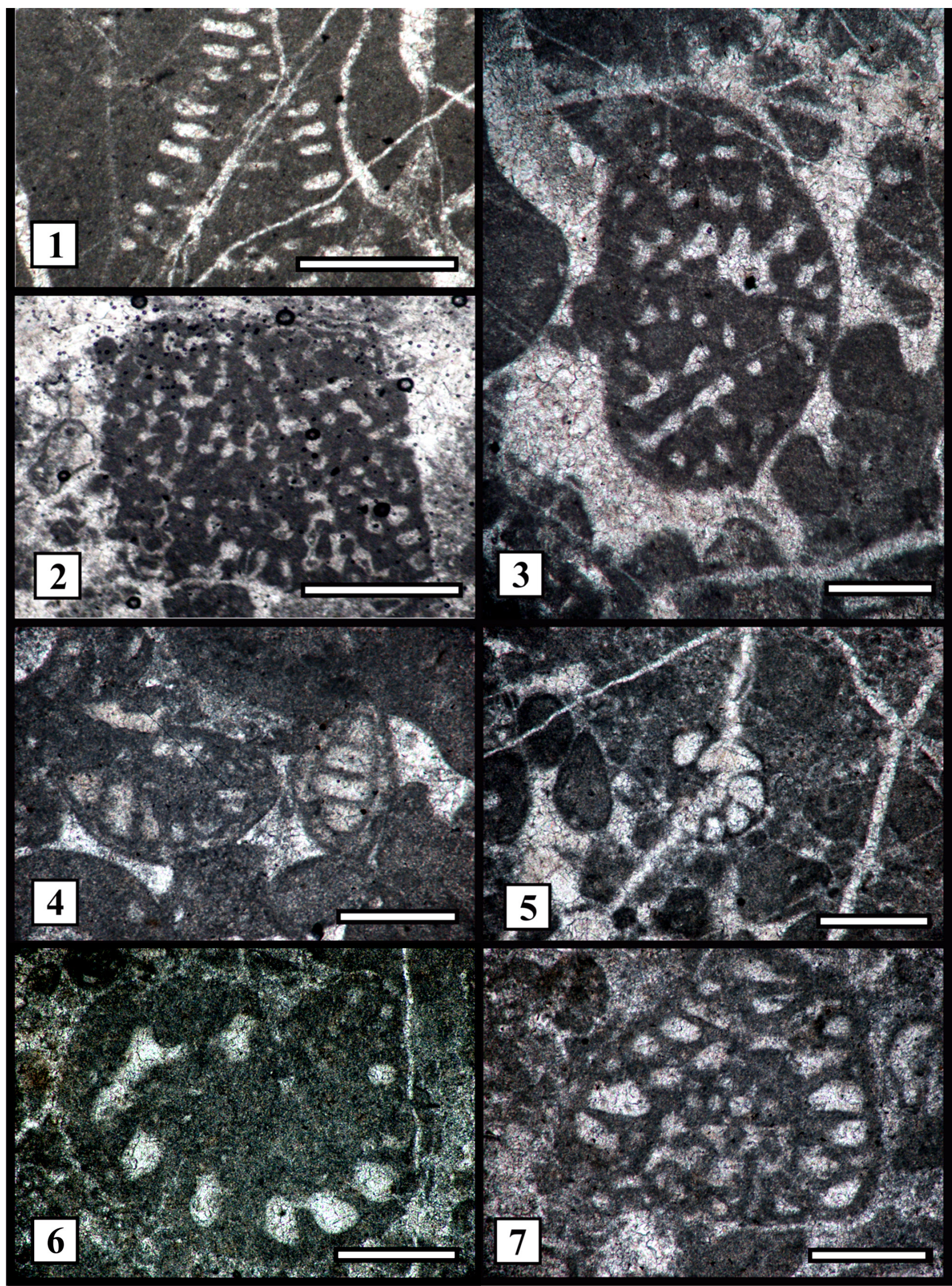


Plate II. Slope and platform edge deposits in the lower part of the carbonate succession in Piatra Craiului. Scale: $1 \mathrm{~mm}$.

Fig. 1. Bioclastic-peloidal rudstone with encrusting organisms and echinoderm plates; Padina Închisă section, sample 50 P;

Fig. 2. Coarse bioclastic grainstone/rudstone with microbial structures, encrusting organisms and bryozoans; West Vlăduşca section, sample 125;

Fig. 3. Bioclastic rudstone. Bioclasts consist of encrusting organisms (Crescentiella morronensis), agglutinated-walled worm tubes, and bivalves; Zaplaz-Lanţuri section, sample 591;

Fig. 4. Bioclastic rudstone. Bioclasts consist of echinoderm plates, gastropods, bivalves, recystalized coral fragments and encrusting organisms [Crescentiella morronensis (Crescenti)]; Padina Lăncii section, sample 686;

Figs. 5, 6. Coral-microbial boundstone with Crescentiella morronensis. Encrusting organisms are present together with the sediment between corals; Fig. 5: Padina Închisă section, sample 40 P; Fig. 6: West Vlăduşca section, sample 138;

Fig. 7. Microsolenid boundstone with peloidal wackestone as internal sediment. Corals are bioeroded; Zaplaz-Lanţuri section, sample 582;

Fig. 8. Coral-microbial boundstone. Superposed crusts of calcareous sponges (Calcistella jachenhausenensis) and stromatolitic-microbial structures on a coral; Padina Lăncii section, sample 717 b. 


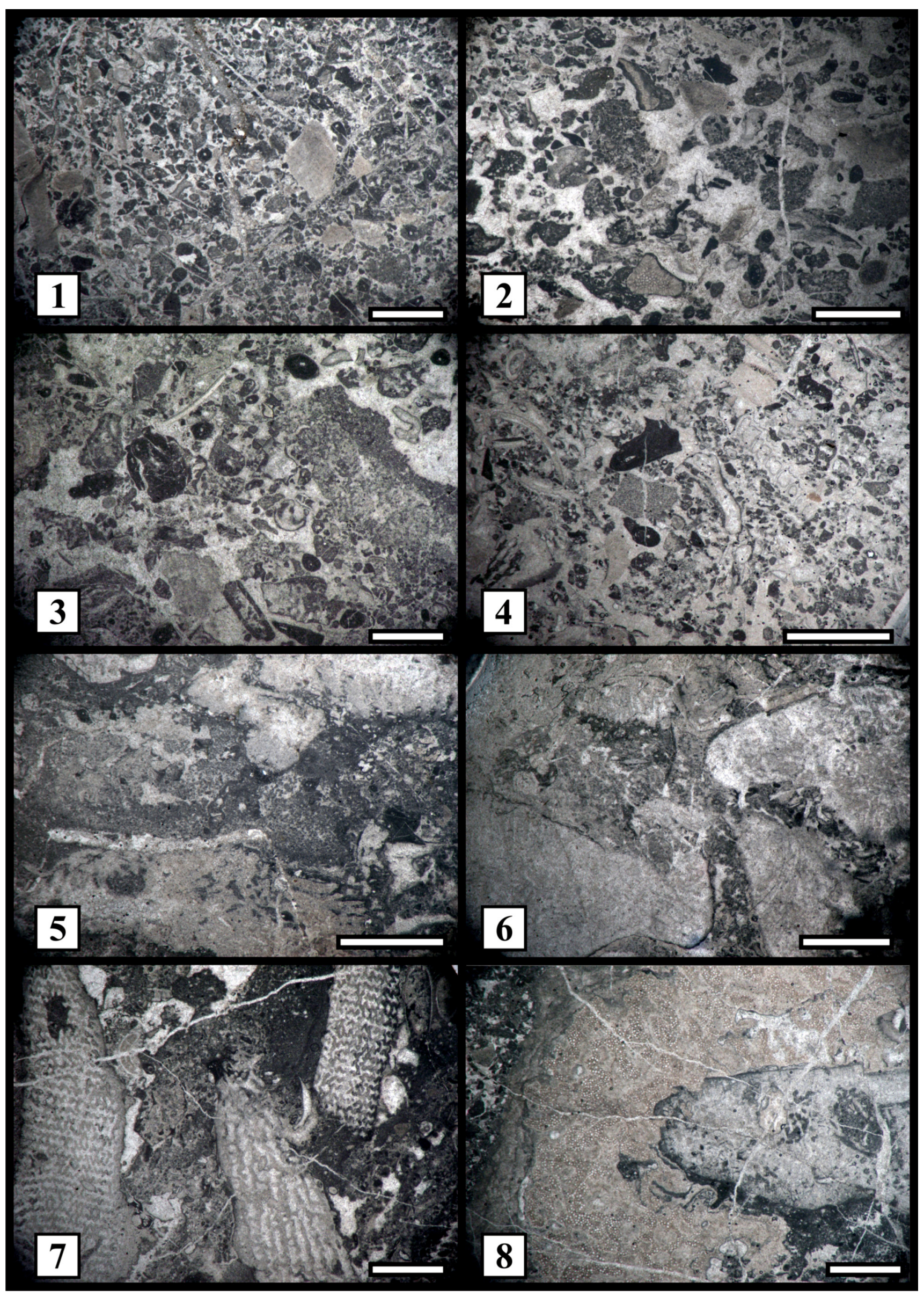


Plate III. Characteristic microfacies of the high-energy internal platform subtidal carbonate deposits. Scale: $1 \mathrm{~mm}$.

Fig. 1. Bioclastic-intraclastic grainstone with black pebbles; West Vlăduşca section, sample 212c;

Fig. 2. Coarse bioclastic grainstone. Bioclasts consist of cyanobacteria, sponge fragments, bivalves and dasycladalean algae (Clypeina sulcata). A micritic envelope around bioclasts is developped; West Vlăduşca section, sample 213;

Fig. 3. Bioclastic-intraclastic, fenestral packstone-grainstone with dasycladalean algae (Salpingoporella pygmaea) and bivalve fragments; ZaplazLanţuri section, sample 630;

Figs. 4, 5. Coarse bioclastic grainstone with cyanobacteria, nerineid gastropods, bivalves and corals. Micritic envelopes around bioclasts; West Vlăduşca section, sample 630;

Fig. 6. Bioclastic-intraclastic, fenestral grainstone with black pebbles; West Vlăduşca section, sample 632;

Figs. 7, 8. Oolitic grainstone with broken and regenerated ooids. Rare bioclasts are represented by gastropods; Padina Închisă section, sample 490. 


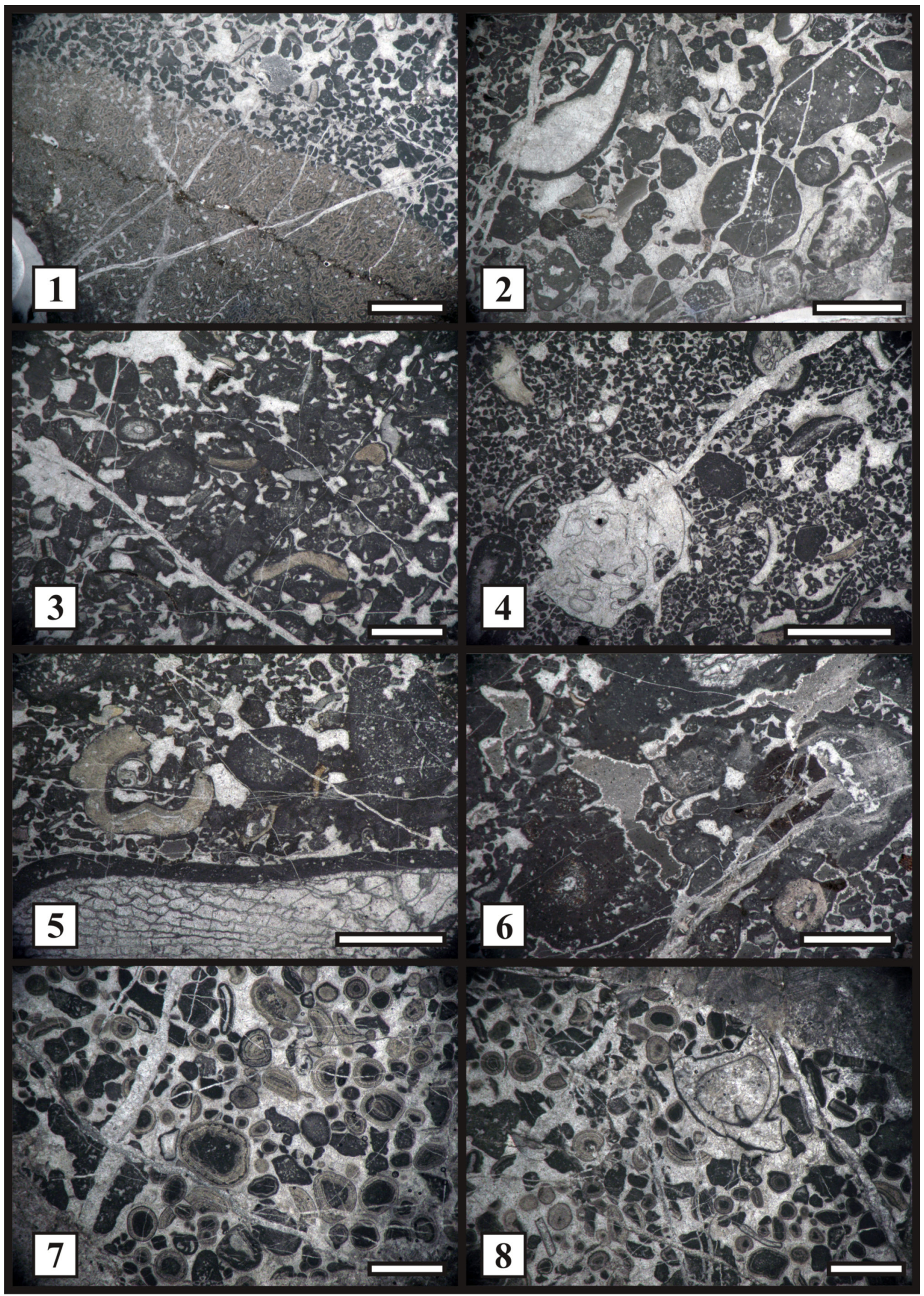


Plate IV. Microfacies of low-energy internal platform subtidal carbonate deposits. Scale: $1 \mathrm{~mm}$.

Fig. 1. Bioclastic-fenestral, bioturbated wackestone with gastropods; Padina Închisă section, sample 435;

Fig. 2. Bioclastic wackestone with diceratid rudists and other bivalve fragments and gastropods. Some cavities are filled with geopetal sediment; Padina Închisă section, sample 468;

Figs. 3, 4. Bioclastic wackestone/floatstone with coral fragments, dasycladalean algae, gastropods and cyanobacteria; Lehmann's Trail section. Fig. 3: sample 621; Fig. 4: sample 621;

Figs. 5, 6. Bioclastic-intraclastic wackestone with dasycladalean algae (Clypeina sulcata); West Vlăduşca section. Fig. 5: sample 197; Fig. 6: sample 197;

Figs. 7, 8. Bioclastic-intraclastic packstone-grainstone. Main bioclasts are represented by foraminifera. Intraclasts contain cyanobacteria nodules; East Vlăduşca section, sample 288. 
PLATE IV

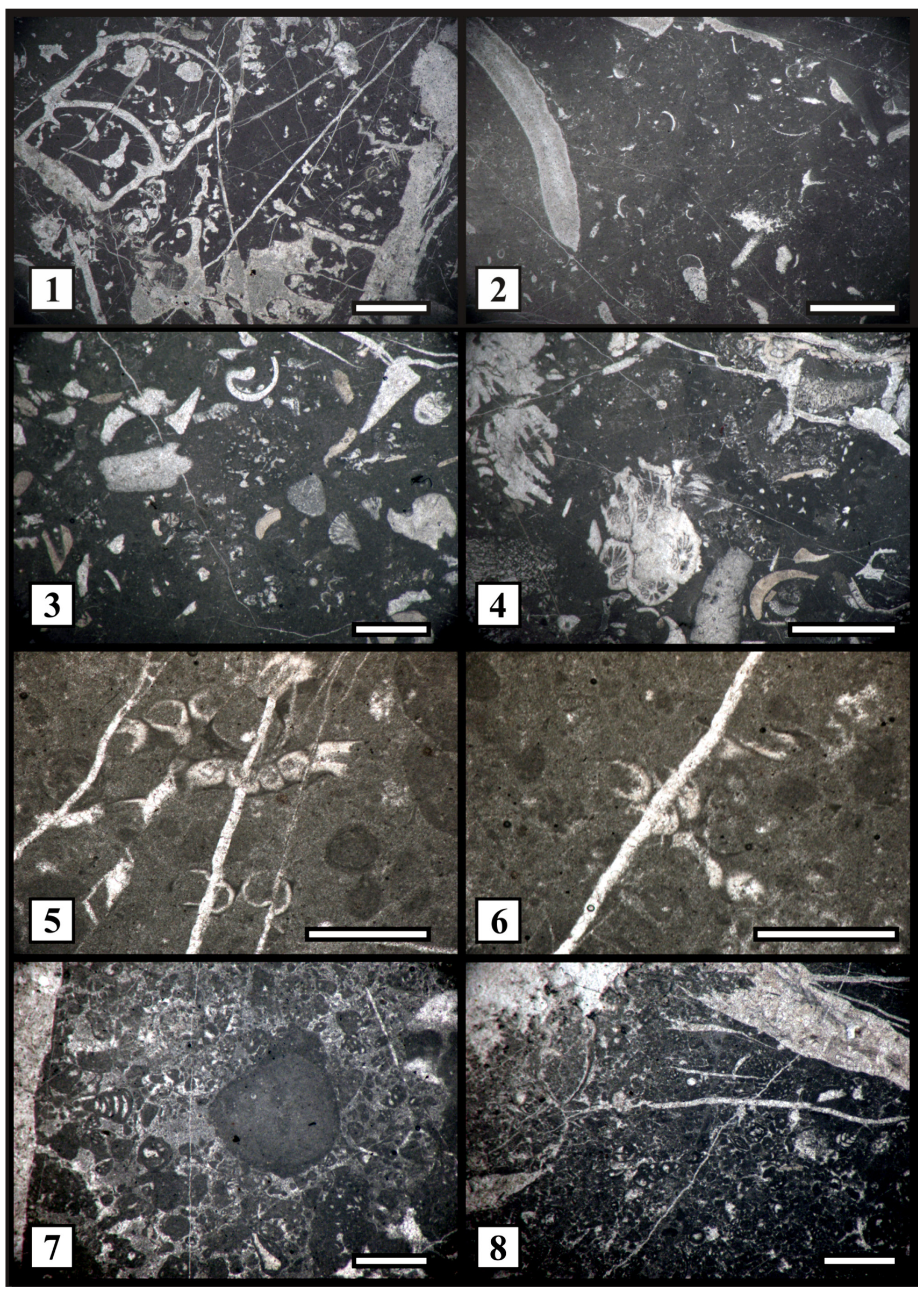


Plate V. Microfacies of intertidal-supratidal carbonate deposits. Scale: $1 \mathrm{~mm}$.

Fig. 1. Microbial laminitic (stromatolitic) structures; Padina Închisă section, sample 454;

Fig. 2. Peloidal fenestral wackestone; West Vlăduşca section; sample 245;

Fig. 3. Peloidal fenestral wackestone sharply overlain by a bioclastic-intraclastic grainstone with cyanobacteria; Lehmann's Trail section, sample 415;

Fig. 4. Rivularicean-type cyanobacteria (Rivularia moldavica Frollo); West Vlăduşca section, sample 242;

Fig. 5. Rivulariacean-type cyanobacteria in a fenestral fabric, West Vlăduşca section, sample 245;

Figs. 6, 7. Bioclastic-fenestral packstone-grainstone with micritized ooids and rivulariacean fragments; East Vlăduşca section, sample 315;

Fig. 8. Intraclastic-bioclastic, fenestral packstone-grainstone with rivulariaceans and gastropods, East Vlăduşca section, sample 316; 
PLATE V

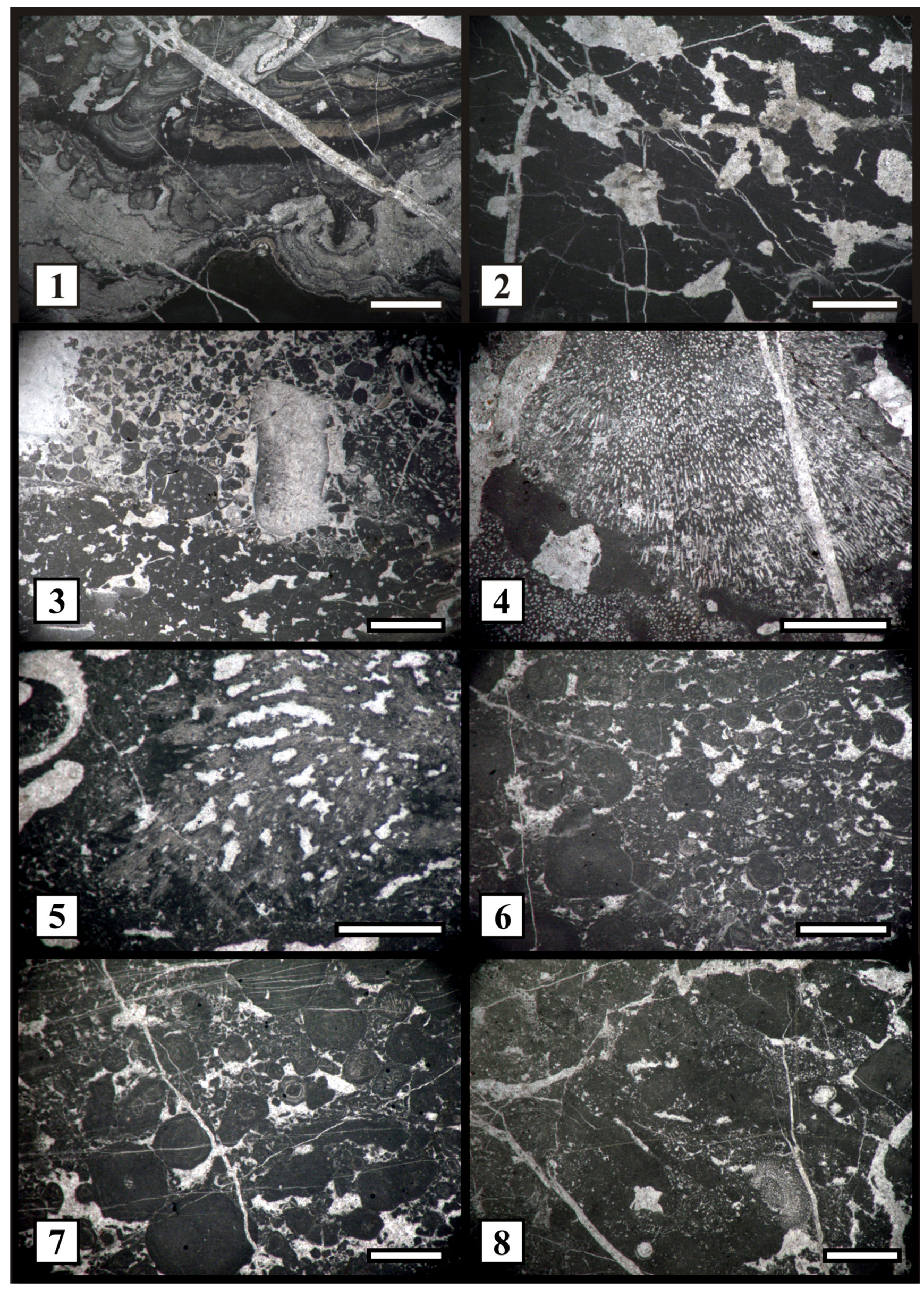


Plate VI. Dasycladalean algae from the reef limestones. Scale: $0.25 \mathrm{~mm}$ (Figs. 1-2; Fig. 4); $0.5 \mathrm{~mm}$ (Fig. 3; Figs. 7-8); 1 mm (Figs. 5-6).

Fig. 1. Clypeina sulcata (Alth), transverse section; Padina Închisă section, sample 30 P;

Fig. 2. Clypeina sulcata (Alth), tangential section; West Vlăduşca section, sample 79;

Fig. 3. Salpingoporella pygmaea (Gümbel), oblique section; Padina Închisă section, sample 40 P;

Fig. 4. Salpingoporella pygmaea (Gümbel), transverse-oblique section; West Vlăduşca section, sample 100;

Figs. 5-8. Petrascula bursiformis (Etallon); Padina Lăncii section, sample 721; Fig. 5: oblique and oblique-transverse sections; Fig. 6: tangential and oblique sections; Fig. 7: tangential section; Fig. 8: longitudinal section of a head fragment. 


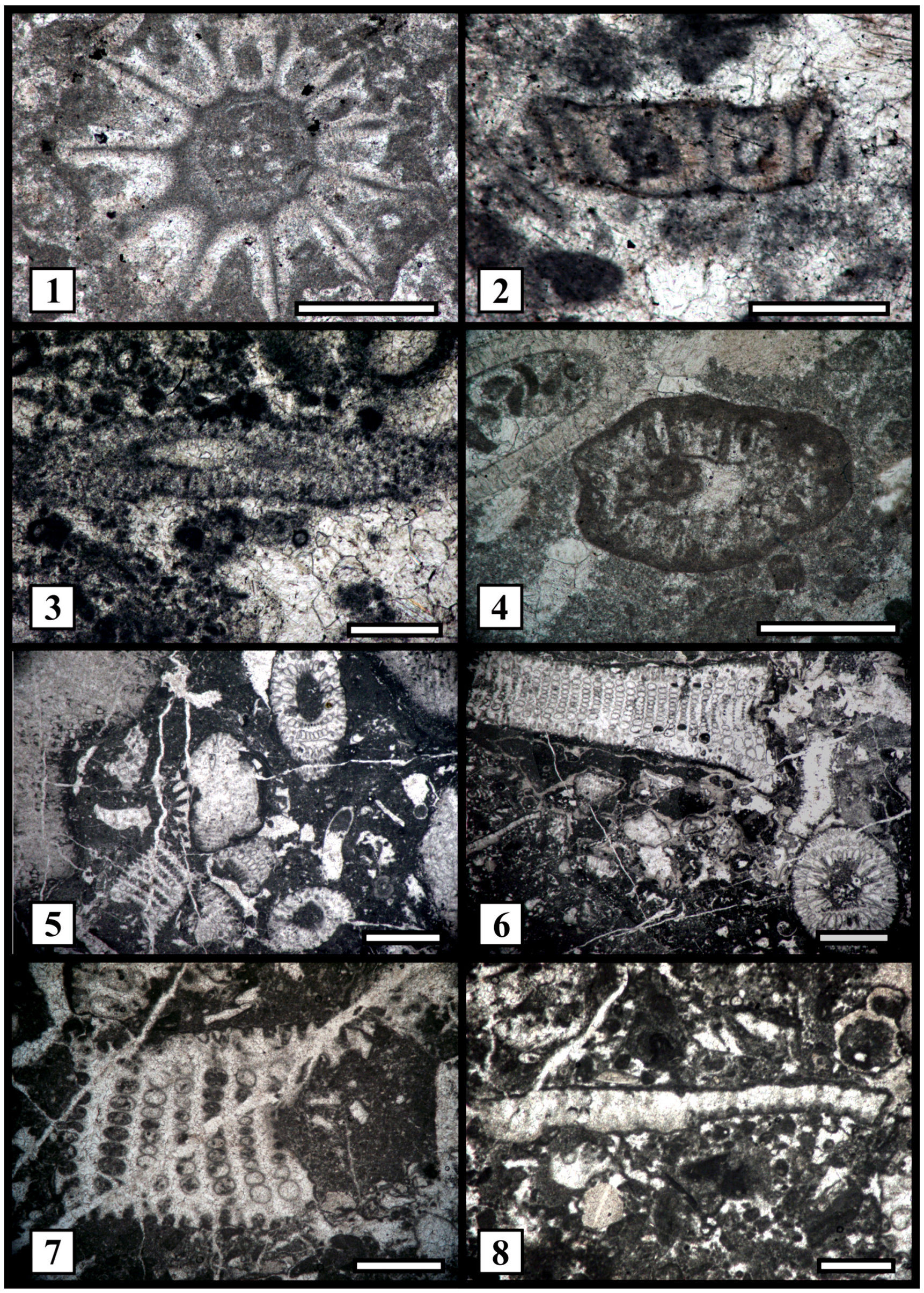


Plate VII. Dasycladalean algae from the high-energy internal platform subtidal carbonates. Scale: 0.25 mm (Figs. 1-2, Fig.5); 0.5 mm (Figs. 3-4; Figs. 6-8).

Fig. 1. Salpingoporella pygmaea (Gümbel), oblique section; Padina Închisă section, sample 71 P;

Figs. 2, 3. Salpingoporella annulata Carozzi. Fig. 2: oblique section; Padina Închisă section, sample 464; Fig. 3: transverse and longitudinal oblique sections; Zaplaz-Lanţuri section, sample 628;

Fig. 4. Steinmanniporella kapelensis (Sokač and Nikler), transverse-oblique section; West Vlăduşca section, sample 218;

Figs. 5, 6. Clypeina sulcata (Alth), Zaplaz-Lanţuri section. Fig. 5: transverse section, sample 650; Fig. 6: transverse and tangential sections, sample 651; Figs. 7, 8. Campbelliella striata (Carozzi), Zaplaz-Lanţuri section. Fig. 7: oblique section, sample 630; Fig. 8: longitudinal-tangential section, sample 631. 


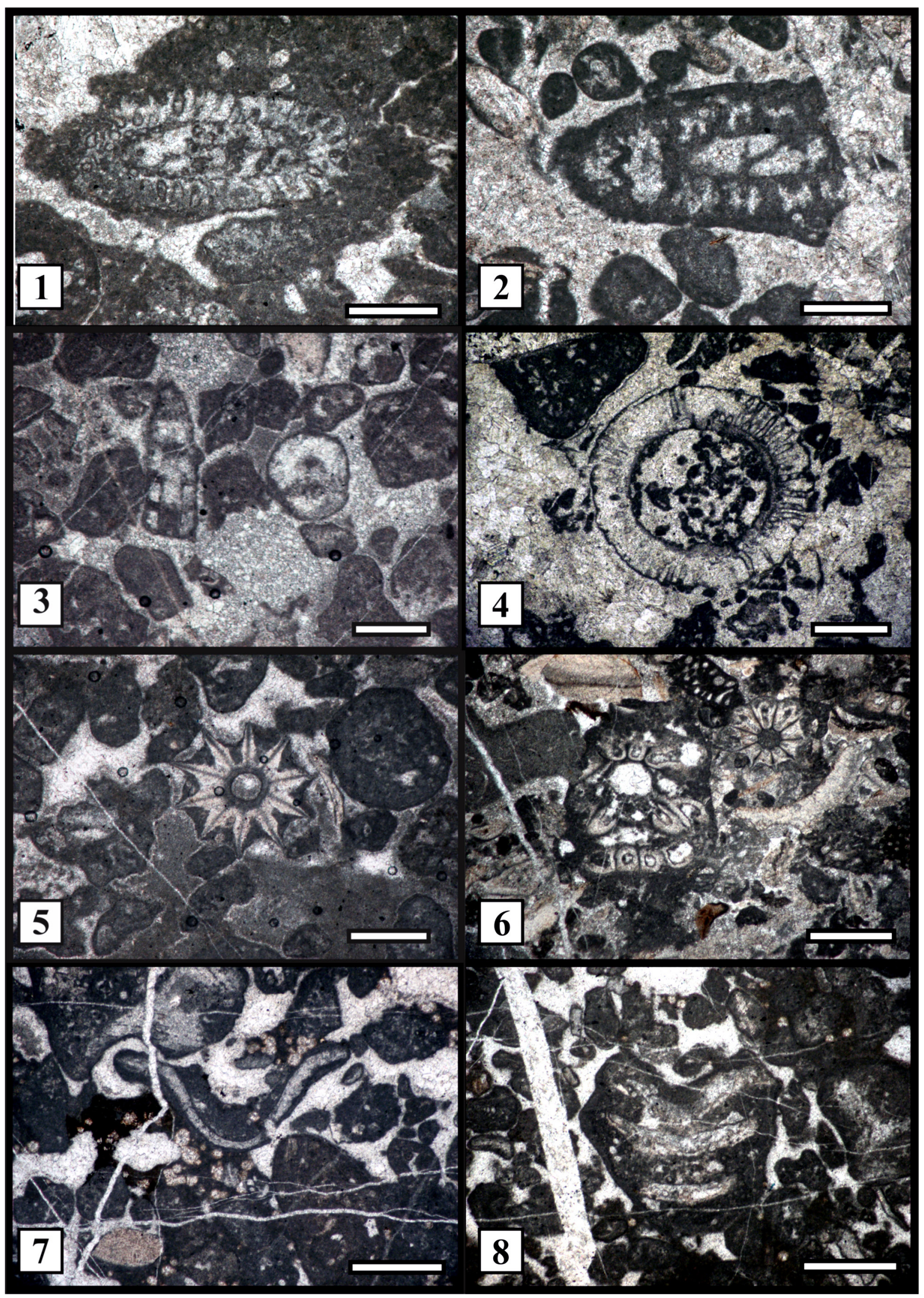


Plate VIII. Dasycladalean algae from the low-energy internal platform subtidal carbonates. Scale: 0.25 mm (Figs. 1-5; Figs. 7-8); 0.5 mm (Fig. 6).

Figs. 1, 2. Clypeina sulcata (Alth), tangential-oblique section; West Vlăduşca section, sample 197;

Figs. 3, 4. Salpingoporella annulata (Carozzi), Padina Închisă section. Fig. 3: oblique section, sample 464; Fig. 4: transverse-oblique section, sample 464;

Fig. 5. Clypeina parasolkani Farinacci \& Radoičić, tranvese-oblique section; Padina Închisă section, sample 464;

Fig. 6. Clypeina sulcata (Alth), longitudinal section cutting five verticils; West Vlăduşca section, sample 197;

Fig. 7. Pseudocymopolia jurassica Dragastan, longitudinal section; Lehmann's Trail section, sample 621;

Fig. 8. Salpingoporella praturloni (Dragastan), fragment of longitudinal section and Protopeneroplis ultragranulata (Gorbatchik), transverse section; Lehmann's Trail section, sample 621; 
PLATE VIII

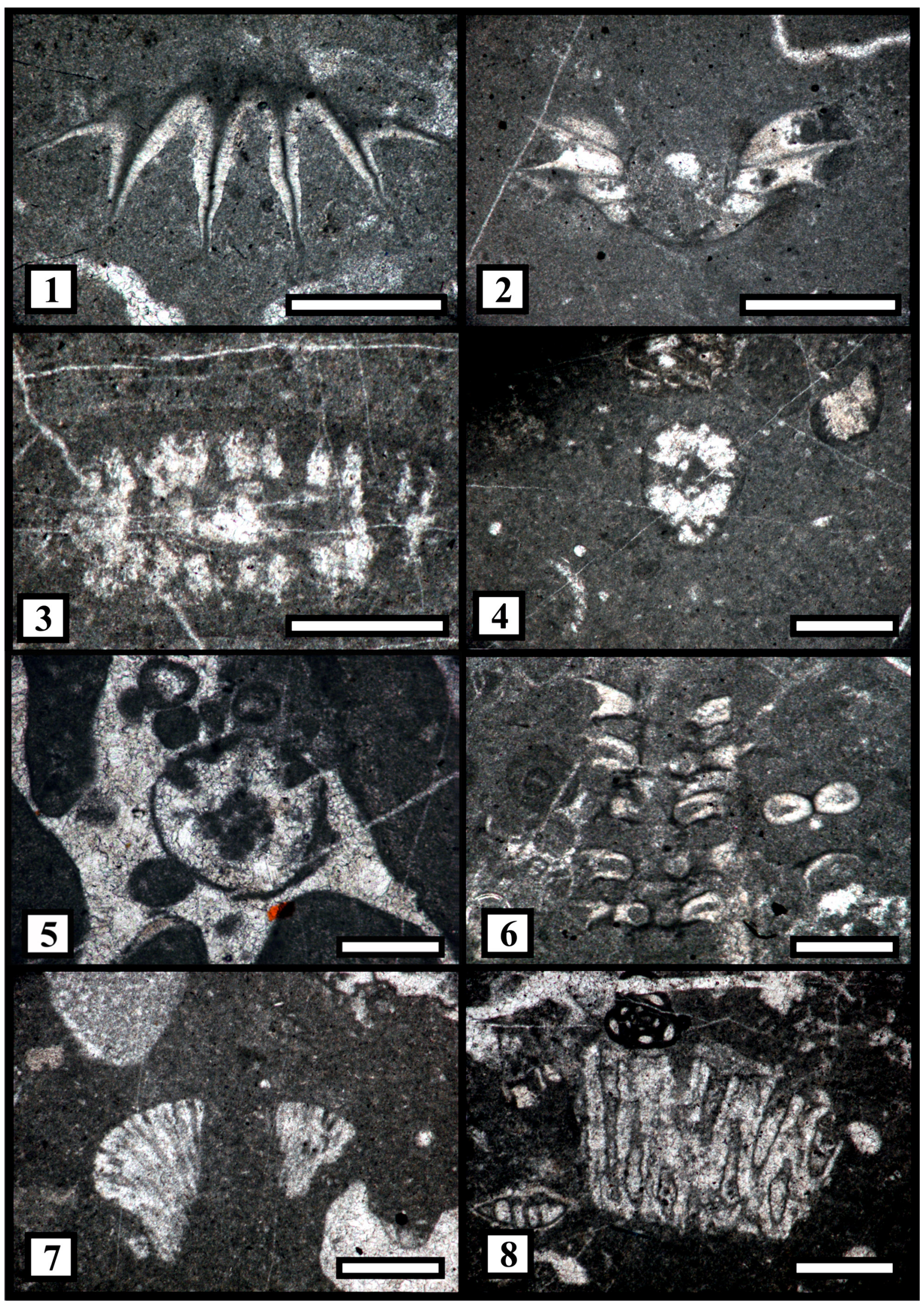

